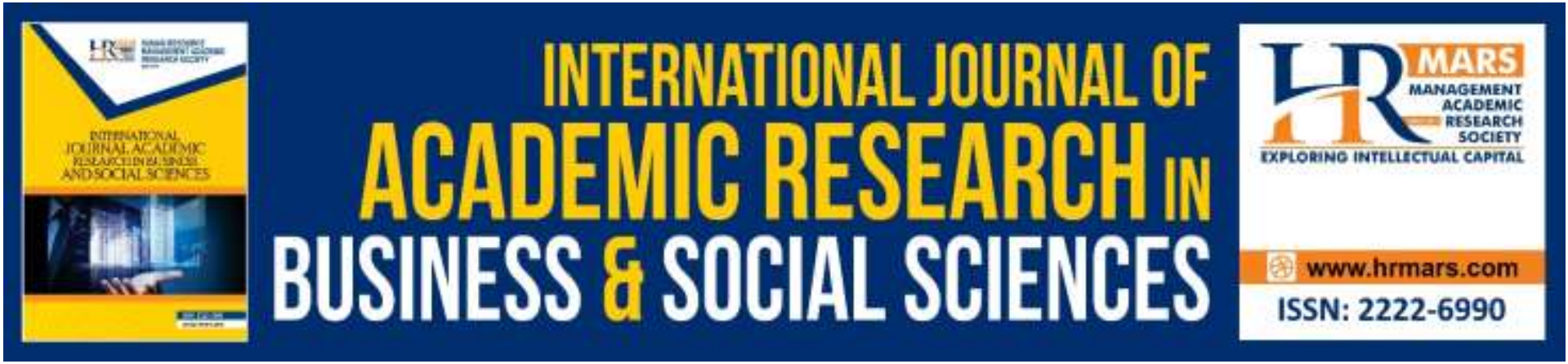

\title{
Does Program fees Affect the Relationship between Lecturers' Competencies and Student' Satisfaction in the Digital Era? A Case of Malaysia Higher Education
}

Muhammad Safuan Abdul Latip, Rachel Yong Yuen May, Mohamad Arif Abdul Kadir, Tan Chee Kwan

To Link this Article: http://dx.doi.org/10.6007/IJARBSS/v9-i7/6187

DOI: 10.6007/IJARBSS/v9-i7/6187

Received: 17 May 2019, Revised: 22 June 2019, Accepted: 23 June 2019

Published Online: 12 July 2019

In-Text Citation: (Latip, May, Kadir, \& Kwan, 2019)

To Cite this Article: Latip, M. S. A., May, R. Y. Y., Kadir, M. A. A., \& Kwan, T. C. (2019). Does Program fees Affect the Relationship between Lecturers' Competencies and Student' Satisfaction in the Digital Era? A Case of Malaysia Higher Education. International Journal of Academic Research in Business and Social Sciences, 9(7), 877-900.

Copyright: (C) 2019 The Author(s)

Published by Human Resource Management Academic Research Society (www.hrmars.com)

This article is published under the Creative Commons Attribution (CC BY 4.0) license. Anyone may reproduce, distribute, translate and create derivative works of this article (for both commercial and non-commercial purposes), subject to full attribution to the original publication and authors. The full terms of this license may be seen at: http://creativecommons.org/licences/by/4.0/legalcode

Vol. 9, No. 7, 2019, Pg. 877 - 900

Full Terms \& Conditions of access and use can be found at http://hrmars.com/index.php/pages/detail/publication-ethics 


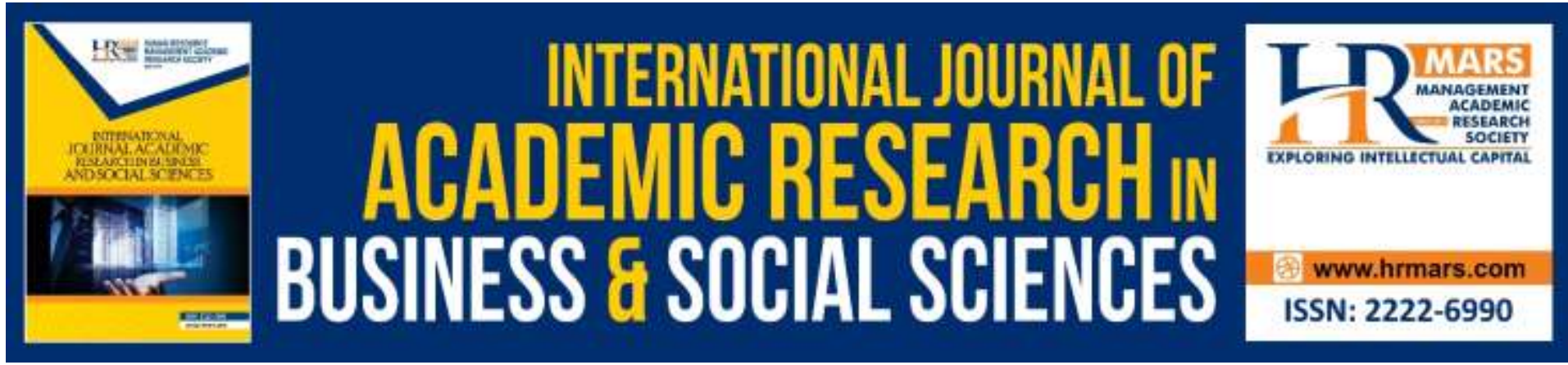

\title{
Does Program fees Affect the Relationship between Lecturers' Competencies and Student' Satisfaction in the Digital Era? A Case of Malaysia Higher Education
}

\author{
Muhammad Safuan Abdul Latip \\ Tunku Abdul Rahman University College, Perak Campus, Malaysia, Universiti Tun Abdul \\ Razak, Malaysia \\ Rachel Yong Yuen May \\ UNITAR International University, Malaysia
}

Mohamad Arif Abdul Kadir

Universiti Teknologi Mara, Malaysia

Tan Chee Kwan

Taylor's University, Malaysia

\begin{abstract}
The research model investigated the effect of lecturers' competencies on students' satisfaction and programme fees through a formative analysis. Notably, the research model included four keys of lecturers' competencies dimensions which are knowledge and credential (Knowledge), pedagogy knowledge and skill (Pedagogy), industrial experience and motivation. The analysis is based on a sample of 386 active students of bachelor's degree onward from eight different Malaysia public and private higher education institutions. The data was collected through a questionnaire survey and analysed using AMOS Software, SPSS and PROCESS by Andrew F. Hayes. The main findings suggested that only knowledge, industrial experience and motivation have positive effects on students' satisfaction. However, the multi-group analysis showed that only industrial experience and motivation are a significant variable for a private institution. Nonetheless, there is no direct significant relationship between lecturers' competencies variables on programme fees. Somehow, programme fees proved to have a significant effect on student satisfaction. Yet surprisingly, the programme fees do not have a mediating effect between lecturers' competencies and students' satisfaction compared to a normal commercial transaction.
\end{abstract}

Keywords: Lecturers' Competencies, Students' Satisfaction, Program Fees, Higher Education, Malaysia 


\section{Introduction}

The transformation of the higher education industry into an actual business critically needed the practices of a competent workforce to respond to the changing of the higher education environment (Potgieter \& Coetzee, 2010). In order to secure a graduate position in the fierce job market, it is essential for a graduate to be equipped with competencies in the related field which included behavior and attitude (Deaconu, Osoian, Zaharie, \& Achim, 2014). Besides, as highlighted on the Graduate Employability Management Scheme (GEMS), the significant challenges in the current job market with low demand for degrees essentially forced graduates to compete. Hence, institutions and lecturers should take responsibility to expose and equip graduates with required competencies. Thus, lecturers' themselves must be competent significantly. This is believed as one of the factors that thoroughly engages and satisfies student which will lead to loyalty between the students' and the institution (Voss \& Gruber, 2006).

The value of loyalty and positive word of mouth is an important competitive advantage in order to compete in today's higher education market (Arambewela \& Hall, 2009). No doubt, good behavior of lecturers as well as their expertise contribute to an excellent input and experience for the students. Indeed, it will assist students extensively in real-life situations. Because of that, scholars emphasized that lecturers are needed to develop and improve their professional competency as a facet of the overall learning process (Prasetio, Azis, Fadhilah, \& Fauziah, 2017). Competent lecturers comprised of a holistic aspect of learning and teaching, including professional knowledge and interaction, social interaction, character as well as personal qualities (Hanapi \& Nordin, 2014). Moreover, Potgieter and Coetzee (2010) highlighted the importance of emotional intelligence to cope with the students and the stressful working environment. As a learning center, subject knowledge and lecturer quality are important because the knowledge transfer is the main activity expected towards knowledge-based societies by stakeholders involved (Awang, 2014). Therefore, the quality of the lecturer will affect the quality of graduates and the institutions involved (Hanapi \& Nordin, 2014). The study has also disclosed that lecturers' competencies affected students' performance notably (Muzenda, 2016). Therefore, lecturers' competencies can have a positive or negative relationship with student overall satisfaction (Douglas, Douglas, \& Barnes, 2006; Khoo, Ha, \& McGregor, 2017; Letcher \& Neves, 2010). Above and beyond that mentioned, student perception with the quality service of the universities is primarily due to the lecturers (Voss \& Gruber, 2006).

Nevertheless, different ranges of program fees charged by the institutions have a potential effect on student expectation and satisfaction (Dwenger, Storck, \& Wrohlich, 2012). As a customer who pays for the services, the students are concerned with the quality of the services provided. An investment (program fees) in the form of initial cost and opportunity cost can potentially affect the relationship between the lecturers' competencies and students' satisfaction (Dwenger et al., 2012). So, by understanding the overall relationship of the proposed variables, it will contribute a clearer insight to the government and universities along the way to a better transformation pathway of education.

\section{Problem Statement}

A statistic from the Ministry of Higher Education (MOHE) indicated a growing number of overall student intakes in both public and private institutions. In addition, the education blueprint forecasted the figures to elevate annually. Based on the statistic, there was a total 
of 511, 154 new students' intake in 2015 and it has increased by 23\% as compared in 2014 which was 412, 878 students. Furthermore, the increasing numbers of higher educational institutions in Malaysia have created pressure. It is not specifically on the private institution, but also public institution involved due to the reduction of the budget from the government. Budget 2017 had announced a spending cut for public universities with a range of between $10 \%$ to $30 \%$. Thus, it forced public institutions to figure out alternatives for financial sustainability. Hence, institutions which are vying for potential students contribute to important reasoning for this study to be conducted as the local institutions are also contending with prestigious international brand universities operating in Malaysia (Tham, 2013).

Teaching ability and subject expertise of the staff are one of the top factors in determining student's satisfaction in higher education (Douglas et al., 2006). The quality of learning also heavily depended on the content of the course, the quality of academic advising, teaching personnel and elective courses available. Therefore, lecturers' competencies are among the greatest attribute that influenced student satisfaction (Seng, 2013). In consequence, as a service industry, it is important to fulfil customer expectation and create customer satisfaction which has potential to produce loyalty and spread a positive word of mouth about the brand (Annamdevula \& Bellamkonda, 2016). Yet, it can also turn into a sour note by dissatisfied customers. Significantly, customers tend to spread negative issues more as compared to a positive experience when the service is excellent. Thus, addressing student satisfaction is necessary in order to compete and ensure the sustainability of institutions (Santhi \& Ganesh, 2015).

Additionally, the program fee charges upsurged the expectation and perception of the student as a customer. The institutions are currently facing pressure to respond with the expectation and the cost involved in running institutions itself. Moreover, Malaysia's cost of tertiary education is rising faster than the Malaysia's inflation rate as compared to other countries like Australia and Indonesia. Hence, it created issues of affordability and quality (Benjamin, Marathamuthu, Muthaiyah, \& Raman, 2011). The survey also disclosed a high graduate unemployment rate and students are facing an education debt upon graduation (Hanapi \& Nordin, 2014). Critically, the effect of program fees on student satisfaction with lecturers' competencies is not well-defined due to the limitations of the study which used program fees to study the relationship between these variables. Apart from that, plenty of studies focused only on student satisfaction and service quality aspect as a general view (Douglas et al., 2006; Letcher \& Neves, 2010; Muzenda, 2016; Santhi \& Ganesh, 2015). Therefore, as a major determinant of quality education, lecturers' competencies have potential in affecting student satisfaction while the program fees charged might give a different understanding which forces the government and universities to change their policies for future education. This is becoming critical due to intense competition, higher expectation as a customer and affordability issues of Malaysians.

\section{Research Objectives}

1. To examine the effect of lecturers' competencies toward students' satisfaction.

2. To determine the effect of lecturers' competencies toward programme fees charge and do programme fees have a direct effect on students' satisfaction.

3. To investigate the mediating effect of programme fees with lecturers' competencies and students' satisfaction. 


\section{Literature Review}

\section{Lecturers' Competencies and Students' Satisfaction}

A competent lecturer plays an important role in student satisfaction and loyalty as a primary determinant in assessing student perception with university service quality (Voss \& Gruber, 2006). This is because the lecturer is a reflection of the graduates and university quality. Hence, lecturers and graduates are carrying the image of the university and have a long impact on institution profitability (Hanapi \& Nordin, 2014). Other than that, the study highlighted the importance of lecturer feedback, easy to communicate and teaching quality as factors contributing toward student satisfaction together with non-academic scope opinion from the lecturer (Arambewela \& Hall, 2009). Lecturer teaching styles and approaches also positively influenced student perception on the quality of the institution. It is achieved through an appropriate decision on teaching styles that assist in better understanding and close relationships that stimulated a better result in student satisfaction (Seng, 2013).

Teaching quality and lecturers' competencies is one of the important variables that contributed to overall student satisfaction (Wong, Tong, \& Wong, 2014). Besides, it is strengthened by the findings of other researches where the academic staffs are an important variable that led to greater student satisfaction which included academic staff support, administrative support, career placement and employability, institutional factor, programme dimension and information system (Santhi \& Ganesh, 2015). Apart from that, a study was conducted in measuring the relationship between students' satisfaction with the higher learning institution (government and private funded) and the results found that academic expertise of a lecturer as a top variable that contributed to students' satisfaction. The student also expected the lecturers to be expert in both, academic and practical aspects especially courses that are classified as hands-on and practical based (Gruber, Fub, Voss, \& GläserZikuda, 2010). Therefore, it clearly indicated a correlation between lecturers' competencies and students' satisfaction.

Lecturers with a good understanding of the subject content will be able to deliver the content effectively and satisfy the student's needs and expectations (Muzenda, 2016). Satisfaction with subject teaching, teaching quality and lecturer feedback found to be significant with the undergraduate student satisfaction. In addition, feedback on student work performance is perceived as valuable by the student for self-improvement and increased their satisfaction level. Furthermore, it also contributed to a sense of attention from the lecturer (Letcher \& Neves, 2010). Research also revealed that teachers with good pedagogical content knowledge, ratified professional belief and motivation as well as enthusiasm in teaching, gained a personal accomplishment as well as a better understanding of students that led to student satisfaction. Motivation and enthusiasm in teaching align with pedagogy knowledge, assisted lecturers in determining a perfect method to deliver a lesson in class and ensure a supreme understanding among students (Kunter et al., 2013). Since students today are becoming more consumer-oriented, the relationship between student and employee is considered as a critical aspect in determining student satisfaction, as they are a tangible aspect of the service. Besides that, to accomplish the institution goal and remain profitable, customer satisfaction is the ultimate aim of the institution (Kashif \& Ting, 2014). 


\section{Program Fees}

Intense competition among institutions in Malaysia has led to a problem of unemployment among graduates. As a fee payer, the student is not a typical customer in any physical commercial transaction because they are looking for the higher value of money and complete experience of learning (Jones, 2010). The research was conducted on the impact of increasing cost on student employment, debt and satisfaction underlined, as currently there is no clear evidence on the impact of programme fees with graduates' outcomes and their financial position upon graduation (Metcalf, 2005). However, it clearly showed a positive relationship between programme fees and graduates debt. This is because there is available loan offers to the students in order to support their studies, especially from lower and middle-income families. Moreover, fees also potentially affect student satisfaction negatively. Due to that, the student tends to consider the cost and how worthwhile their certificates will be before enrolling in any program (Metcalf, 2005).

As a customer that pays the programme fees, expectation and demands of the students will increase unceasingly. They will expect more value as the amount of fees increased on both of the following aspects; the education experience and service support from the university (Jones, 2010). However, students' rights as customers might have a negative influence if students misunderstood their rights as customers of a higher education institution. They can potentially demand difficult aspects which included good grades rather than good services (Jones, 2010).

Additionally, due to limited capacity in a public institution, a private institution will need to take responsibility to meet the demands of the local and international students (Benjamin et al., 2011). A private university that may or may not obtain funds from the government has higher programme fees as compared to government university (Benjamin et al., 2011). Public universities are funded by the government and are having cheaper programme fees as compared to private universities (Azman, Idris, \& Siang, 2014).

The effect of high prices in tuition fees led to a higher cost in order to further study for the students (Dwenger et al., 2012). Thus, it raised an issue of affordability for the lower and middle-income families in Malaysia when planning to further their studies at private universities (Benjamin et al., 2011). However, there is no clear evidence on the effect of programme fees towards student expectation of the service quality and in this context, the lecturers' competencies itself. Thus, it is worth to know as in other commercial transactions, whether the consumer expected less quality on a low price product as compared to high priced products with a similar function. Because the study on goods purchase behaviour found that there is a significant positive relationship between the price perception of customers and their purchase intention. It is also proven that price perception significantly influenced their satisfaction with the price and service quality offered (Munnukka, 2008). However, there is no clear evidence on the service product category especially on the higher education area although there are significant studies on debt upon graduation and the increasing cost of tertiary education in Malaysia. Numerous studies indicated a positive relationship between teaching quality and student satisfaction (Douglas et al., 2006; Gruber et al., 2010; Kunter et al., 2013; Letcher \& Neves, 2010; Muzenda, 2016; Santhi \& Ganesh, 2015; Wong et al., 2014). However, whether programme fees mediated the relationship between lecturers' competencies and students' satisfaction remains unclear. 


\section{Methodology}

The study is a fundamental type of research, categorized as a causal type of study deliberately done in order to test whether one variable causes another variable to change (Sekaran \& Bougie, 2016). Besides, the study is considered as a causal study when two different groups of people are involved in the study (Briggs, Coleman, \& Morrison, 2012). Hence, it is lined up with the purpose of the study, to investigate the relationship between a private and a public institution.

This is a quantitative type of study using primary data and disproportionate stratified random sampling. The survey is in the form of a standardized self-administered questionnaire and the respondents are expected to understand the questions in the same way. The noncontrived study is applied to study the phenomena of the natural environment (Sekaran \& Bougie, 2016). The natural setting is able to produce findings that are away from the opinions and hopes of the researcher. Therefore, the findings are not affected by the researcher's beliefs. On the aspect of the time horizon, the cross-sectional study was used where the data is collected once in order to answer the research questions. The study was also not intended to compare the findings from a different point of the time. Therefore, a cross-sectional study was utilized.

In the context of this study, Bachelor degree, Master degree and Ph.D. students are the targeted population. Only new registered and currently enrolled (active) students in Malaysia are involved. The alumnis are not considered as the population of study because they could come from different ages where the education transformation might not have taken place yet. Therefore, it will lead to a contradicting perception of what is being experienced by the current student on the current market, competition, service and program fees in an institution.

Table 1. Population and sample size of the study

\begin{tabular}{cccc}
\hline Total population & $\begin{array}{c}\text { Acceptable margin } \\
\text { of error }\end{array}$ & Confidence level & Required sample \\
\hline $1,055,245$ & $5 \%$ & $95 \%$ & 384 \\
\hline
\end{tabular}

The population of the study is 1,055,245 elements (S.A. Salam, personal communication, August 1, 2017). The margin of error used by the researcher is $5 \%$. This is the maximum (plus or minus) figure of sampling error. Whereby $5 \%$ is acceptable in the case of any miscalculation. The general rule rate of acceptable margin role in business and education research is established as 5\% especially for categorical data (Ary, Razavieh, \& Jacobs, 1996). Another author also stated that the suitable margin of error for categorical data or known as discrete data is $5 \%$ while continuous data is $3 \%$ (Hassan \& Ghazali, 2012). The confidence level of the sample size is $95 \%$ in order to ensure a reliable result. Hence, a required sample size of the research is 384 respondents (minimum) with a 95\% confidence level and 5\% acceptable margin of error (Sekaran \& Bougie, 2016). The data were collected at eight different institutions as listed below. Meanwhile, a pilot study was conducted which involved 30 respondents from Universiti Tun Abdul Razak. 
Table 2. List of Universities Involved

\begin{tabular}{cll}
\hline & \multicolumn{1}{c}{ List of Universities } \\
\hline \multirow{2}{*}{ PUBLIC } & 1 & Universiti Teknologi Mara (UiTM) \\
& 2 & Universiti Putra Malaysia (UPM) \\
& 3 & Universiti Teknologi Malaysia (UTM) \\
& 4 & Universiti Malaya (UM) \\
PRIVATE & 1 & Universiti Tun Abdul Razak (UNIRAZAK) \\
& 2 & Infrastructure University Kuala Lumpur (IUKL) \\
& 3 & Universiti Kuala Lumpur (UNIKL) \\
\hline
\end{tabular}

\section{Results and Analysis}

\section{Respondent Profile}

Majority of the respondents are female. Besides, $87.3 \%$ of the respondents are pursuing undergraduate studies. Thus, it explains the reason why the majority of the respondent are age between 18 to 29 years old. $96.1 \%$ of the respondents are local students and the rest which is equivalent to $3.9 \%$ are international students. Majority of the respondents are public institution students with a total of 210, while another 176 respondents are private institution students.

Table 3. The Respondents' Profile

\begin{tabular}{|c|c|c|c|}
\hline & & Frequency $(\mathrm{N}=386)$ & Percentage (\%) \\
\hline \multirow[t]{2}{*}{ Gender } & Female & 277 & 71.8 \\
\hline & Male & 109 & 28.2 \\
\hline \multirow[t]{3}{*}{ Age } & 40 and above & 2 & 0.5 \\
\hline & 30 to 39 & 13 & 3.4 \\
\hline & 18 to 29 & 371 & 96.1 \\
\hline \multirow[t]{5}{*}{ Religion } & Others & 9 & 2.3 \\
\hline & Hindu & 31 & 8.0 \\
\hline & Christian & 13 & 3.4 \\
\hline & Buddhist & 17 & 4.4 \\
\hline & Islam & 316 & 81.9 \\
\hline \multirow[t]{2}{*}{ Education } & Master degree / Ph.D. & 49 & 12.7 \\
\hline & Bachelor degree & 337 & 87.3 \\
\hline \multirow[t]{2}{*}{ Students } & International student & 15 & 3.9 \\
\hline & Malaysian student & 371 & 96.1 \\
\hline \multirow[t]{2}{*}{ Institution } & Private University/ College & 176 & 45.6 \\
\hline & Public University/ College & 210 & 54.4 \\
\hline \multirow[t]{2}{*}{ Previous institution } & Different & 218 & 56.5 \\
\hline & Same & 168 & 43.5 \\
\hline
\end{tabular}




\section{Statistical Analysis}

The Structural Equation Modelling (SEM) through Analysis of Moment Structure (AMOS), Statistical Package for Social Science (SPSS) and PROCESS were used by the study to analyses the data. The hypothesis testing uses multiple regression analysis to validate the relationship between the variables. Besides, the multiple regression analysis was conducted to test the hypothesis of the study. Data screening had been conducted to ensure accurate data been decoded. The maximum and minimum descriptive analysis had been conducted for data screening purposes. Thus, a problem during the process of decoding can be traced and correction can be made accordingly. The data have also been analyzed using Box Plot analysis in order to eliminate extreme and invalid data. Result of the normality test as shown in Figure 1 with a normal outlier and no extreme value in the data. All data had been confirmed statistically on the accuracy through the methods explained before being tested. Therefore, the final numbers of valid data are found to be 386 students. Meanwhile, the required sample size for this study is 384 students. Thus, the data is sufficient and valid. 

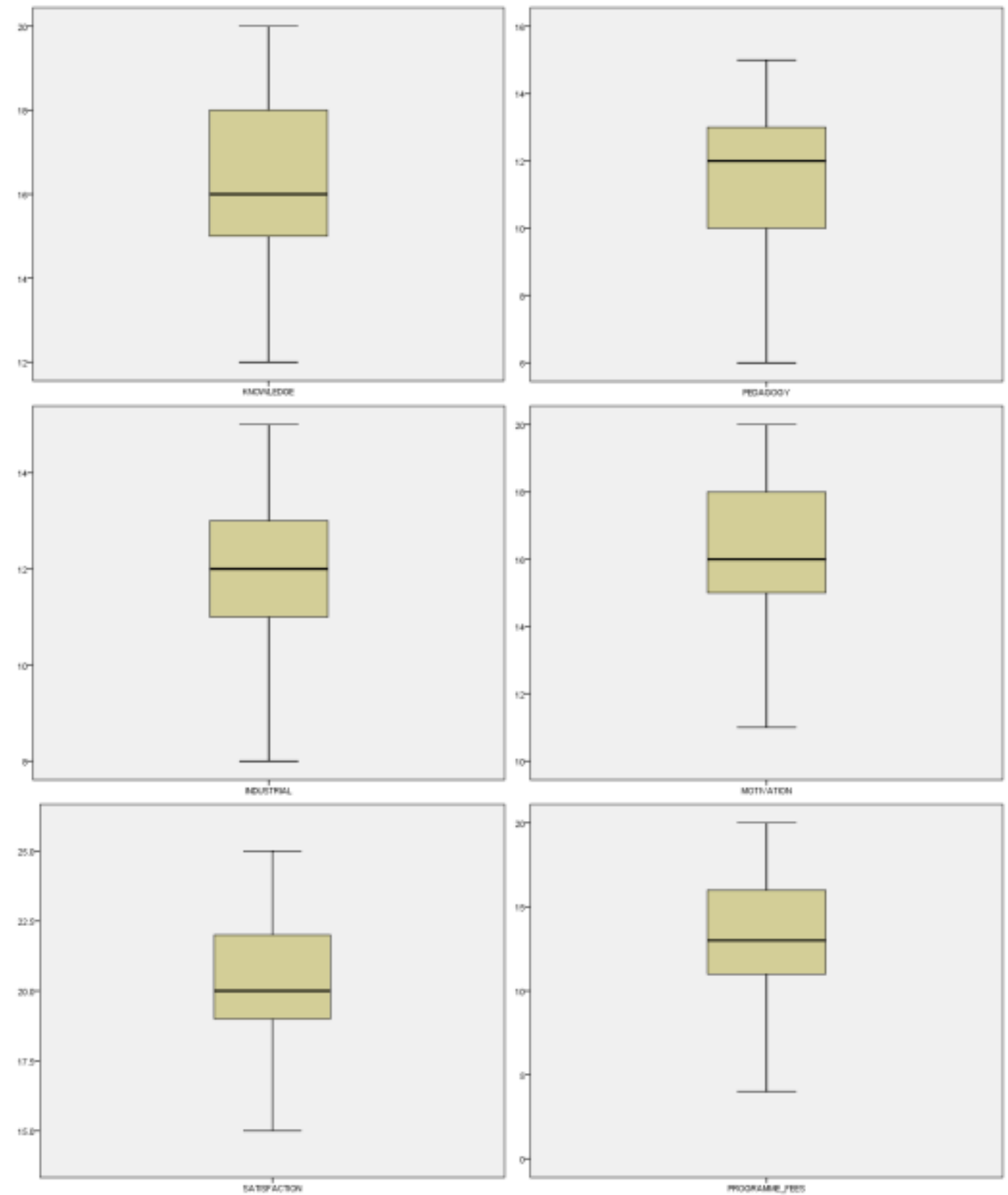

Figure 1. Summary of box plot analysis for normality test

Based on Table 4, the overall Cronbach's Alpha score of the instruments is 0.704 and it is sufficient to indicate a consistent of the scales internally (Phan, Abdallah, \& Matsui, 2011). 
Table 4. Summary of Cronbach's Alpha result

\begin{tabular}{|c|c|c|c|c|c|}
\hline Variables & Mean & $\begin{array}{l}\text { Standard } \\
\text { deviation }\end{array}$ & $\begin{array}{l}\text { Corrected } \\
\text { item-total } \\
\text { correlation }\end{array}$ & $\begin{array}{l}\text { Cronbach's } \\
\text { Alpha if item } \\
\text { deleted }\end{array}$ & $\begin{array}{l}\text { No. of } \\
\text { items }\end{array}$ \\
\hline \multicolumn{6}{|l|}{ Dependent variable } \\
\hline $\begin{array}{l}\text { Students' } \\
\text { satisfaction }\end{array}$ & 12.306 & 1.616 & .632 & .620 & 3 \\
\hline \multicolumn{6}{|c|}{ Independent variables } \\
\hline Knowledge & 12.723 & 1.606 & .646 & .765 & 3 \\
\hline Pedagogy & 11.565 & 1.879 & .586 & .773 & 3 \\
\hline Industrial experience & 11.904 & 1.839 & .540 & .783 & 3 \\
\hline Motivation & 12.140 & 1.758 & .660 & .759 & 3 \\
\hline \multicolumn{6}{|l|}{ Moderating variable } \\
\hline Programme fees & 13.153 & 3.368 & .171 & .829 & 4 \\
\hline \multicolumn{3}{|c|}{ Overall Cronbach's Alpha } & \multicolumn{3}{|c|}{ No of variables } \\
\hline \multicolumn{3}{|c|}{0.704} & \multicolumn{3}{|c|}{6} \\
\hline
\end{tabular}

\section{Confirmatory Factor Analysis (CFA)}

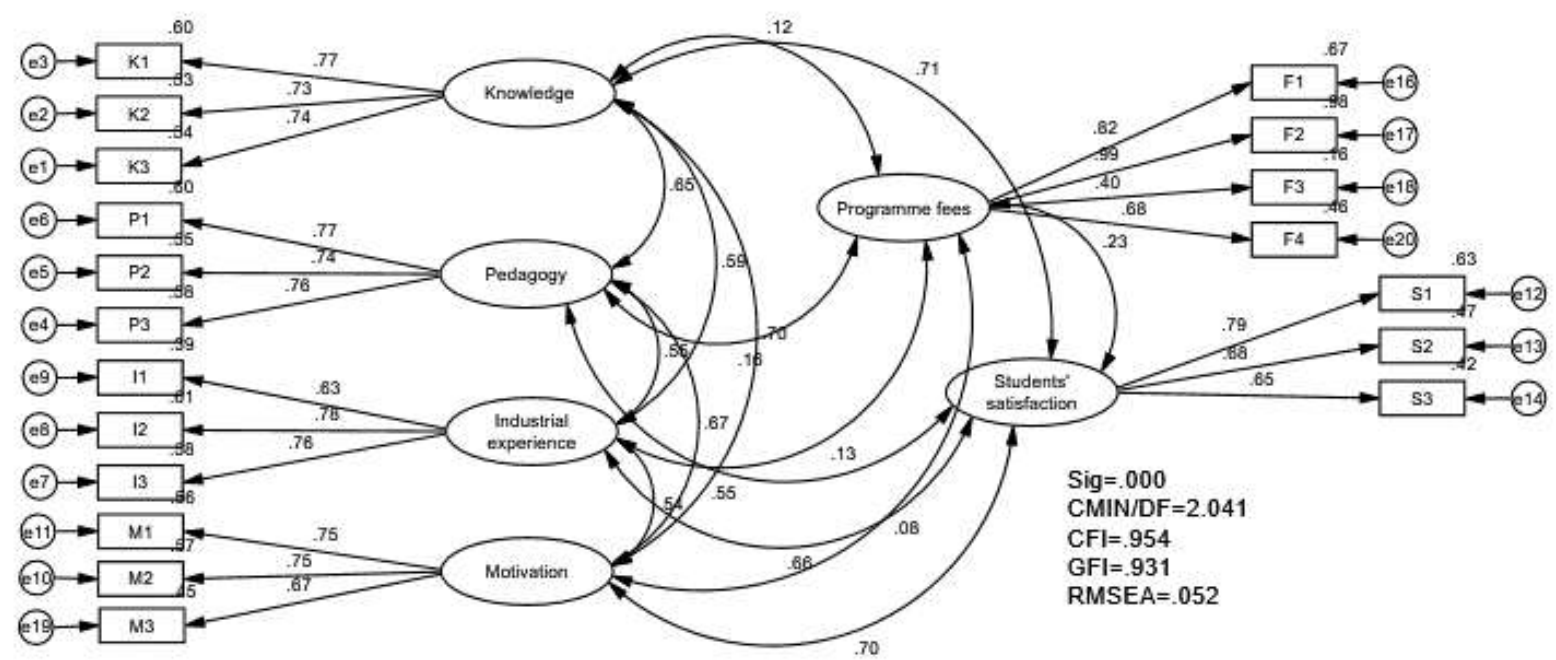

Figure 2. Confirmatory Factor Analysis (CFA) result

The CFA was tested on the construct to ensure reliable data of the study. The model fitness scores good fitness for the study. The Comparative fix index (CFI) score .954 indicates that all latent variables are uncorrelated. The score of .90 and above is needed as suggested to ensure a good measurement of the independence model (Hooper, Coughlan, \& Mullen, 2008). The goodness-of-fit statistic (GFI) score suggested to be at least 0.90 shows a good proportion of variance is accounted for the covariance of the estimated population and the model score.931 (Hooper et al., 2008). Also, the root mean square error of approximation (RMSEA) of the model is .052. It shows how well the model with optimal chosen parameter estimates fit the population covariance matrix (Byrne, 1998). Thus, the model score was below .08 as suggested by the researcher and it indicated a good fit of the model (Hooper et al., 2008). 


\section{Convergent Validity, Construct Validity and Discriminant Validity}

The validity of the data has been tested. The convergent validity is achieved with a score of more than .05. Its purpose was to measure the construct using the score of average variance extracted (AVE). Besides, the composite reliability (CR) of the construct also exceeding 0.6 for all construct that indicates good composite reliability of the instrument (Awang, Hui, \& Zainudin, 2018). The discriminant validity is achieved as the discriminant validity index summary in Table 6 show that the diagonal value each of the construct is higher than the value of the item under its column.

Table 5. Summary of the CR and AVE of the instruments.

\begin{tabular}{|c|c|c|c|c|c|}
\hline Construct & Item & Question & Load. factor & CR & AVE \\
\hline \multirow[t]{3}{*}{ Knowledge } & K1 & $\begin{array}{l}\text { Well-qualified lecturer (Kashif \& Ting, } \\
\text { 2014). }\end{array}$ & 0.77 & 0.79 & 0.56 \\
\hline & K2 & $\begin{array}{l}\text { Good experience on the subject (Kashif } \\
\& \text { Ting, 2014). }\end{array}$ & 0.73 & & \\
\hline & K3 & $\begin{array}{l}\text { Excellent explanation on the subject } \\
\text { (Kashif \& Ting, 2014). }\end{array}$ & 0.74 & & \\
\hline \multirow[t]{3}{*}{ Pedagogy } & P1 & Attractive teaching technique. & 0.78 & 0.80 & 0.58 \\
\hline & P2 & $\begin{array}{l}\text { Active participation in class (Moreno- } \\
\text { Murcia, Silveira Torregrosa, \& Belando } \\
\text { Pedreño, 2015) }\end{array}$ & 0.74 & & \\
\hline & P3 & $\begin{array}{l}\text { Facilitating teaching material (Moreno- } \\
\text { Murcia et al., 2015) }\end{array}$ & 0.76 & & \\
\hline \multirow[t]{3}{*}{ Industrial experience } & I1 & $\begin{array}{l}\text { Industrial experience input during class } \\
\text { (Carter \& Yeo, 2016). }\end{array}$ & 0.63 & 0.77 & 0.53 \\
\hline & 12 & Wide industrial experiences. & 0.78 & & \\
\hline & 13 & Real industry application. & 0.77 & & \\
\hline \multirow[t]{3}{*}{ Motivation } & M1 & $\begin{array}{l}\text { Importance of teaching on students' } \\
\text { performance (Watjatrakul, 2014). }\end{array}$ & 0.74 & 0.77 & 0.53 \\
\hline & $\mathrm{M} 2$ & $\begin{array}{l}\text { The concern of the lecturer (Watjatrakul, } \\
\text { 2014). }\end{array}$ & 0.76 & & \\
\hline & M3 & Energetic lecturer. & 0.68 & & \\
\hline \multirow[t]{4}{*}{ Programme fees } & F1 & The fees is lower. & 0.82 & 0.83 & 0.57 \\
\hline & $\mathrm{F} 2$ & The fees are reasonable. & 0.99 & & \\
\hline & F3 & $\begin{array}{l}\text { The fees are at the same range as } \\
\text { another similar type of institution. }\end{array}$ & 0.40 & & \\
\hline & $\mathrm{F} 4$ & $\begin{array}{l}\text { I get valuable education for the fees I } \\
\text { paid (Tuan, 2012). }\end{array}$ & 0.68 & & \\
\hline \multirow[t]{3}{*}{ Students' satisfaction } & S2 & $\begin{array}{l}\text { Satisfied with knowledge theory of the } \\
\text { lecturer. }\end{array}$ & 0.79 & 0.75 & 0.50 \\
\hline & S3 & $\begin{array}{l}\text { Satisfied with industrial experience of } \\
\text { the lecturer. }\end{array}$ & 0.68 & & \\
\hline & S4 & Satisfied overall with the lecturer. & 0.66 & & \\
\hline
\end{tabular}


Table 6. Discriminant validity index summary

\begin{tabular}{lrrrrrr}
\hline Construct & $\begin{array}{l}\text { Students' } \\
\text { satisfactio } \\
\text { n }\end{array}$ & Knowledge & Pedagogy & $\begin{array}{l}\text { Industrial } \\
\text { experience }\end{array}$ & $\begin{array}{l}\text { Motivatio } \\
\mathrm{n}\end{array}$ & $\begin{array}{l}\text { Program } \\
\text { me fees }\end{array}$ \\
\hline $\begin{array}{l}\text { Students' } \\
\text { satisfaction }\end{array}$ & $\mathbf{0 . 7 1}$ & & & & & \\
Knowledge & 0.71 & 0.75 & & & & \\
$\begin{array}{l}\text { Pedagogy } \\
\text { Industrial }\end{array}$ & 0.55 & 0.65 & $\mathbf{0 . 7 6}$ & & & \\
$\begin{array}{l}\text { experience } \\
\text { Motivation }\end{array}$ & 0.66 & 0.59 & 0.55 & $\mathbf{0 . 7 3}$ & & \\
$\begin{array}{l}\text { Programme } \\
\text { fees }\end{array}$ & 0.70 & 0.70 & 0.67 & 0.54 & $\mathbf{0 . 7 3}$ & \\
\hline
\end{tabular}

\section{Lecturers' Competencies, Program Fees and Student Satisfaction}

Based on Figure 3, the CMIN/DF of the model shows a score of 2.401. Meanwhile, the GFI (.931) and CFI (.954) scored close to 1 , which considered being as a considerable good fit of the model. The RMSEA value of .052 on the model indicated a good fit of the model on the level of freedom (Hooper et al., 2008). Thus, the model scored a good RMSEA because below .080 .

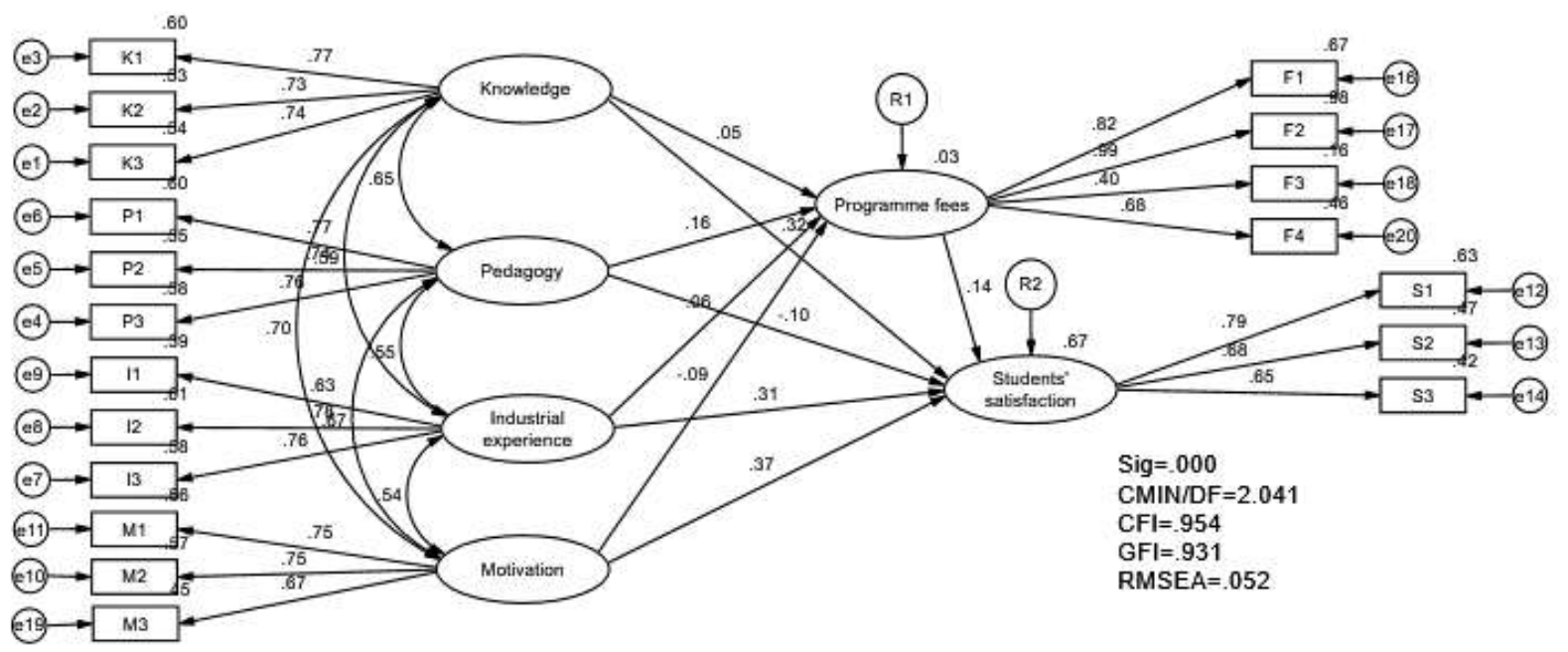

Figure 3. Analysis of lecturers' competencies and students' satisfaction 
Table 7. Result analysis of lecturers' competencies and students' satisfaction

\begin{tabular}{|c|c|c|c|c|c|c|}
\hline \multicolumn{3}{|c|}{ Relationship tested } & Estimate & S.E. & C.R. & $\mathbf{P}$ \\
\hline Knowledge & $\rightarrow$ & Programme fees & 0.10 & 0.22 & 0.44 & 0.66 \\
\hline Pedagogy & $\rightarrow$ & Programme fees & 0.29 & 0.18 & 1.60 & 0.11 \\
\hline Industrial experience & $\rightarrow$ & Programme fees & 0.11 & 0.14 & 0.75 & 0.45 \\
\hline Motivation & $\rightarrow$ & Programme fees & -0.17 & 0.20 & -0.83 & 0.40 \\
\hline Knowledge & $\rightarrow$ & Students' satisfaction & 0.34 & 0.10 & 3.42 & $* * *$ \\
\hline Pedagogy & $\rightarrow$ & Students' satisfaction & -0.09 & 0.08 & -1.18 & 0.24 \\
\hline Industrial experience & $\rightarrow$ & Students' satisfaction & 0.27 & 0.07 & 4.21 & $* * *$ \\
\hline Motivation & $\rightarrow$ & Students' satisfaction & 0.36 & 0.09 & 3.88 & $* * *$ \\
\hline Programme fees & $\rightarrow$ & Students' satisfaction & 0.07 & 0.02 & 3.05 & $* *$ \\
\hline
\end{tabular}

Based on the formative analysis (Table 7), the results show none of the lecturers' competencies variables is statistically significant in a relationship with the programme fees ( $p$-value more than .05). However, the analysis of the relationship between lecturers' competencies variables and students' satisfaction found that, out of four variables, three variables were statistically significant. When knowledge goes up by 1 , Student' satisfaction goes up by 0.34 with a $p$-value of 0.001 . Meanwhile, when the industrial experience goes up by 1 , students' satisfaction increase by 0.27 with a $p$-value of 0.001 . When motivation is up by 1 , students' satisfaction goes up by 0.36 with a $p$-value of 0.001 . However, pedagogy is not statistically significant as the $p$-value score more than .05 . Besides, programme fees do have a statistically significant relationship toward students' satisfaction as the $p$-value score is 0.01 .

\section{Multi-group Analysis (Private and public institutions)}

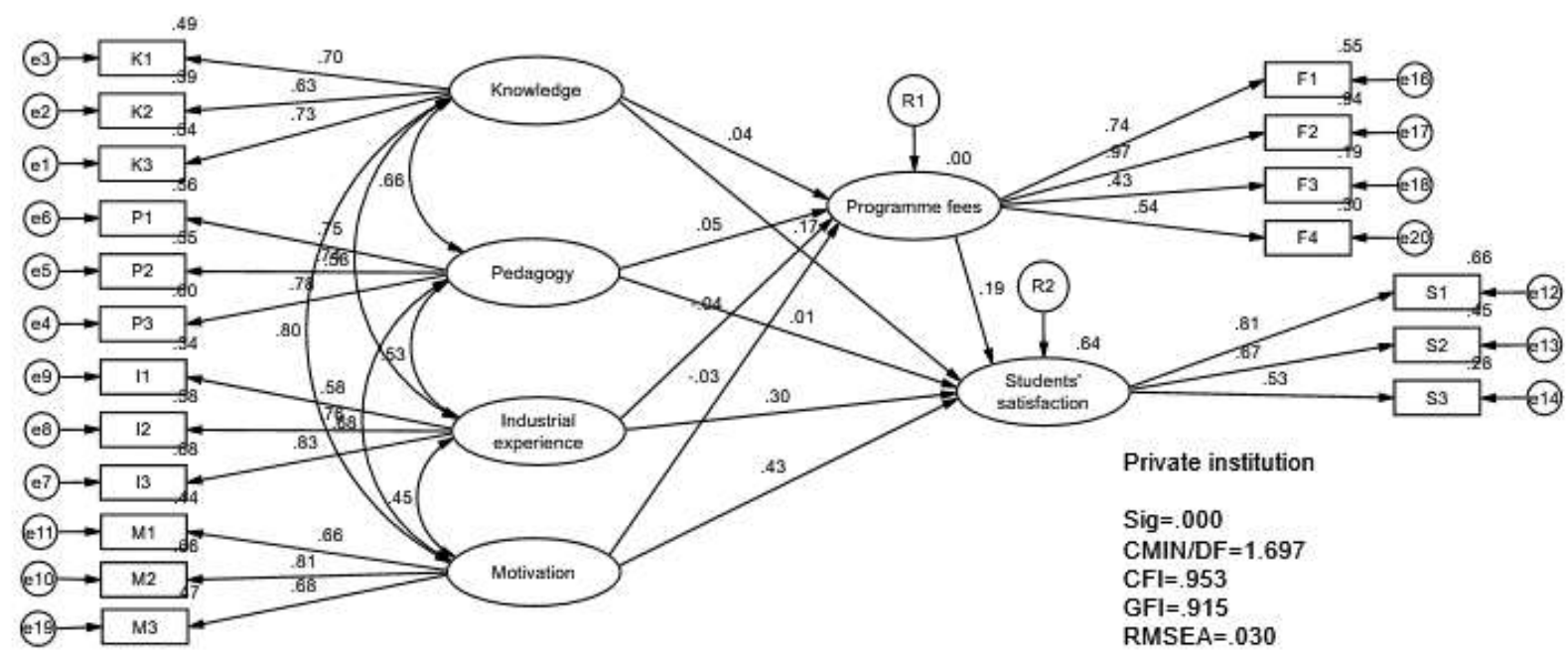

Figure 4. Analysis of lecturers' competencies and student satisfaction (Private institution) 
Based on Figure 4 and Figure 5, the CMIN/DF score for multi-group analysis on private and public institutions independently is 1.697. Meanwhile, the GFI (0.915) and CFI (.935) scored close to 1 which considered as a good fit of the data. The RMSEA value of .03 on the model indicated a good fit of the model on the level of freedom because of the score below 08 (Hooper et al., 2008).

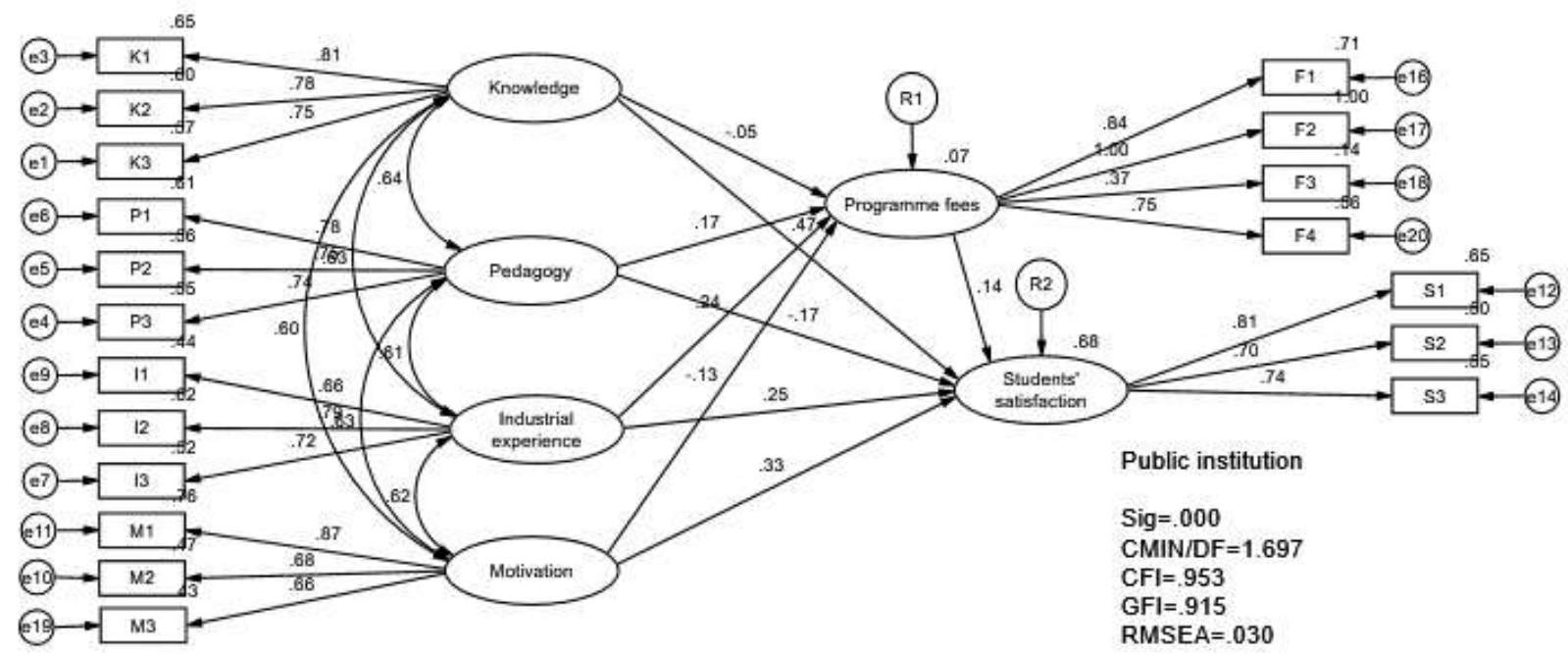

Figure 5. Analysis of lecturers' competencies and student satisfaction (Public institution) The multi-group analysis of the private institution (Figure 5) having the same result as the main group study (Figure 3). None of the lecturers' competencies variables is statistically significant as the $p$-value score more than .05 . However, the result on the relationship between lecturers' competencies variables and students' satisfaction found that knowledge and pedagogy is not statistically significant with a $p$-value more than .05 . Meanwhile, the result indicates a statistically significant relationship between program fees and students' satisfaction variable with a $p$-value of .01).

Further, the multi-group analysis of the public institution (Figure 5) found a different result on the tested variables. Although the industrial experience found to be not statistically significant toward program fees, somehow the $p$-value is almost reaching .05 at 0.64 . In the meantime, the relationship tested between lecturers' competencies and students' satisfaction found a similar result as the main group analysis (Figure 3), with three statistically significant variables which are knowledge, industrial experience and motivation. Besides, the program fees also found to have a positive relationship toward students' satisfaction with a $p$-value below 05 . 
Table 8. Result analysis of lecturers' competencies and student satisfaction (Multi-Group)

\begin{tabular}{|c|c|c|c|c|c|c|}
\hline \multicolumn{3}{|c|}{ Relationship tested } & Estimate & S.E. & C.R. & $\mathbf{P}$ \\
\hline \multicolumn{7}{|c|}{ PUBLIC INSTITUTION } \\
\hline Knowledge & $\rightarrow$ & Programme fees & -0.102 & 0.275 & -0.372 & 0.71 \\
\hline Pedagogy & $\rightarrow$ & Programme fees & 0.378 & 0.276 & 1.368 & 0.171 \\
\hline Industrial experience & $\rightarrow$ & Programme fees & 0.457 & 0.247 & 1.852 & 0.064 \\
\hline Motivation & $\rightarrow$ & Programme fees & -0.308 & 0.294 & -1.046 & 0.296 \\
\hline Knowledge & $\rightarrow$ & Students' satisfaction & 0.501 & 0.117 & 4.287 & $* * *$ \\
\hline Pedagogy & $\rightarrow$ & Students' satisfaction & -0.177 & 0.112 & -1.577 & 0.115 \\
\hline Industrial experience & $\rightarrow$ & Students' satisfaction & 0.236 & 0.101 & 2.341 & $*$ \\
\hline Motivation & $\rightarrow$ & Students' satisfaction & 0.382 & 0.123 & 3.112 & $* *$ \\
\hline Programme fees & $\rightarrow$ & Students' satisfaction & 0.068 & 0.028 & 2.387 & $*$ \\
\hline \multicolumn{7}{|c|}{ PRIVATE INSTITUTION } \\
\hline Knowledge & $\rightarrow$ & Programme fees & 0.061 & 0.382 & 0.159 & 0.874 \\
\hline Pedagogy & $\rightarrow$ & Programme fees & 0.069 & 0.201 & 0.346 & 0.729 \\
\hline Industrial experience & $\rightarrow$ & Programme fees & -0.054 & 0.159 & -0.342 & 0.732 \\
\hline Motivation & $\rightarrow$ & Programme fees & -0.034 & 0.28 & -0.121 & 0.903 \\
\hline Knowledge & $\rightarrow$ & Students' satisfaction & 0.187 & 0.226 & 0.827 & 0.408 \\
\hline Pedagogy & $\rightarrow$ & Students' satisfaction & 0.008 & 0.118 & 0.065 & 0.948 \\
\hline Industrial experience & $\rightarrow$ & Students' satisfaction & 0.261 & 0.096 & 2.725 & $* *$ \\
\hline Motivation & $\rightarrow$ & Students' satisfaction & 0.375 & 0.17 & 2.199 & $*$ \\
\hline Programme fees & $\rightarrow$ & Students' satisfaction & 0.131 & 0.048 & 2.726 & $* *$ \\
\hline \multicolumn{7}{|c|}{ Note: ${ }^{*} p<0.05 .{ }^{* *} p<0.01 .{ }^{* * *} p<0.001}$. \\
\hline
\end{tabular}




\section{Mediation Effect}

PROCESS by Andrew F. Hayes was used to observed variables analysis through OLS regression in SPSS for mediating effect (Hayes, 2013). The results are as below.

Table 9. Mediation result using PROCESS

\begin{tabular}{|c|c|}
\hline \multicolumn{2}{|r|}{ Mediation path analysis } \\
\hline \multicolumn{2}{|r|}{$X$ predicting $M$ (path $A$ ) } \\
\hline Knowledge & $b=-.02, t(381)=-.12, p<0.001$ \\
\hline \multicolumn{2}{|r|}{ Covariates } \\
\hline Pedagogy & $b=.22, t(381)=1.94, p .905$ \\
\hline Industrial experience & $b=.07, t(381)=.67, p .500$ \\
\hline Motivation & $b=.05, t(381)=.42, p .674$ \\
\hline \multicolumn{2}{|r|}{ M predicting $Y$ (path $B$ ) } \\
\hline Programme fees & $b=.06, t(380)=3.41, p<0.001$ \\
\hline \multicolumn{2}{|r|}{ Covariates } \\
\hline Knowledge & $b=.25, t(380)=5.05, p<0.001$ \\
\hline Pedagogy & $b=.02, t(380)=.50, p .619$ \\
\hline Industrial experience & $b=.24, t(380)=6.16, p<0.001$ \\
\hline Motivation & $b=.26, t(380)=5.86, p<0.001$ \\
\hline \multicolumn{2}{|r|}{$X$ predicting $Y($ path $C)$} \\
\hline Knowledge & $b=.25, t(381)=4.96, p<0.010$ \\
\hline \multicolumn{2}{|r|}{ Covariates } \\
\hline Pedagogy & $b=.03, t(381)=.83, p .408$ \\
\hline Industrial experience & $b=.24, t(381)=6.20, p<0.010$ \\
\hline Motivation & $b=.26, t(381)=5.85, p<0.001$ \\
\hline \multicolumn{2}{|c|}{ Indirect effect $=-.001, S E=.009,95 \% \mathrm{Cl}[-.020, .018]$} \\
\hline *There are no mediat & ect because $\mathrm{Cl}$ includes zero. \\
\hline
\end{tabular}

PROCESS analysis found that there is no mediation effect of programme fees between lecturers' competencies variables and students' satisfaction as the $\mathrm{Cl}$ includes zero in the indirect effect relationship (Hayes, 2013). Therefore, programme fees do not mediate the relationship between lecturers' competencies and students' satisfaction. 


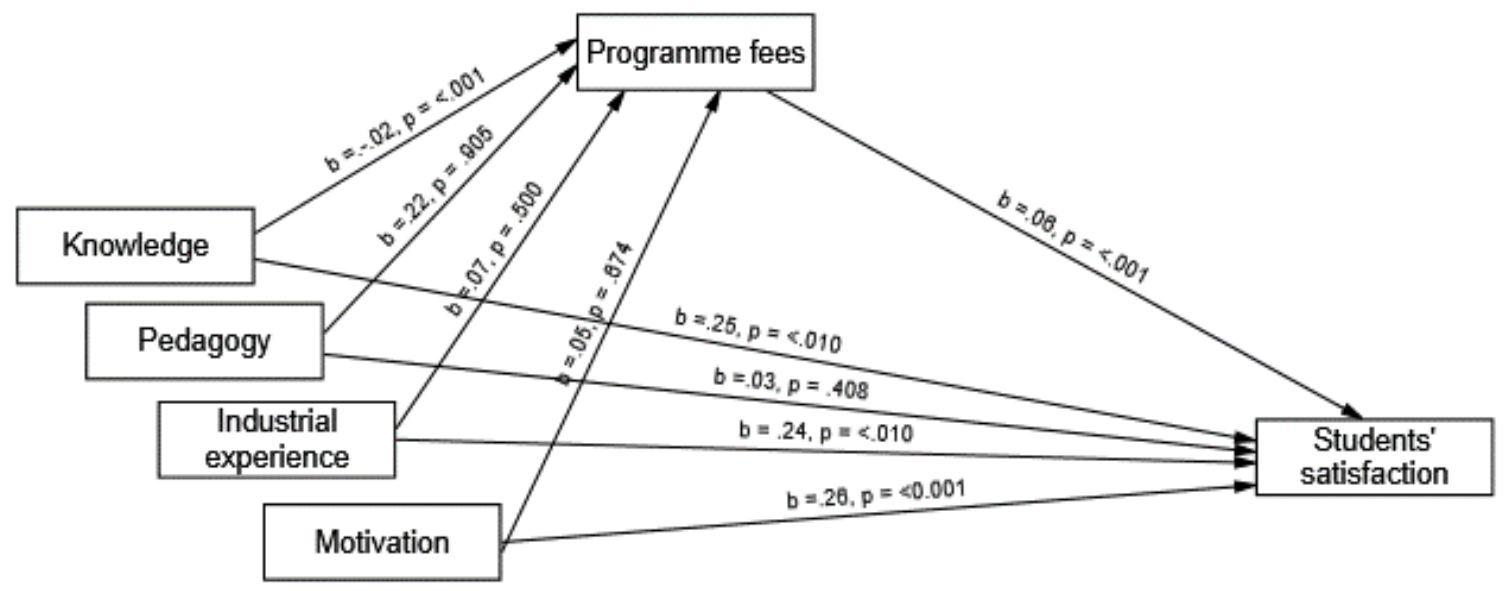

Direct effect $=b=.246, p=<.001$

Indirect effect $=-.001, \mathrm{SE}=.009,95 \% \mathrm{Cl}[-.020, .018]$

Figure 6. Mediation path result

Table 10. Summary of hypotheses tested

\begin{tabular}{|c|c|c|}
\hline \multicolumn{2}{|c|}{ Hypotheses } & \multirow{2}{*}{$\frac{\text { Result }}{\text { Accepted }}$} \\
\hline H1 & $\begin{array}{l}\text { Lecturers' knowledge and credential influence students' satisfaction toward the } \\
\text { university. }\end{array}$ & \\
\hline H2 & $\begin{array}{l}\text { Lecturers' pedagogy knowledge and skill influence students' satisfaction toward the } \\
\text { university. }\end{array}$ & Rejected \\
\hline H3 & Lecturers' industrial experience influence students' satisfaction toward the university. & Accepted \\
\hline H4 & Lecturers' motivation influence students' satisfaction toward the university. & Accepted \\
\hline H5 & $\begin{array}{l}\text { Lecturers' knowledge and credential have a significant effect on the programme fees } \\
\text { charge. }\end{array}$ & Rejected \\
\hline H6 & $\begin{array}{l}\text { Lecturers' pedagogy knowledge and skill have a significant effect on the programme fees } \\
\text { charge. }\end{array}$ & Rejected \\
\hline H7 & Lecturers' industrial experience has a significant effect on the programme fees charge. & Rejected \\
\hline H8 & Lecturers' motivation has a significant effect on the programme fees charge. & Rejected \\
\hline H9 & $\begin{array}{l}\text { The programme fees charge has a positive effect on students' satisfaction toward the } \\
\text { university. }\end{array}$ & Accepted \\
\hline H10 & $\begin{array}{l}\text { Programme fees mediates the relationship between lecturers' competencies and } \\
\text { students' satisfaction }\end{array}$ & Rejected \\
\hline
\end{tabular}

\section{Discussion}

The analysis conducted found that out of four variables, only three variables of lectures' competencies were significant toward students' satisfaction which are knowledge, industrial experience and motivation. The knowledge found to be statistically significant due to the fact that knowledge transfer and learning are the main activities conducted in the institution. It is also expected by the students and another stakeholder when reviewed about education institution. As the main activities conducted was learning and mastering the theoretical knowledge of the program, thus it justified the significance of this variable. Multi-group 
analysis on the public institutions individually also found a statistically significant relationship on knowledge. Somehow, the relationship is statistically insignificant in the private institution group. Although, it can be concluded that knowledge is an important indicator that contributed towards students' satisfaction. The findings found to be parallel and supported by the previous study (Awang, 2014; Douglas et al., 2006).

The second variable which indicated a statistically significant relationship toward student satisfaction is the industrial experience. In the era of industrial evolution and demand from the employer on the industry input among graduates theoretically, the variable contributed towards the significant relationship of industrial experience. As the competition among graduates are getting intense and supported with the high unemployment rate among graduates, the students and other stakeholders expect the lecturers to be knowledgeable, not only on the theory aspect of the program but the practicality and industry input on the program (Awang, 2014). The academic world and industry will require to have a good linkage to come out with a comprehensive program in the institution. While the industry is lacking a competent workforce, thus the institution mainly the lecturers is an active agent in order to ensure graduates are competent in order to supply the workforce demand from the industry. Besides, as the competition is getting intense in job seeking, thus the stakeholders involved including parents will expect the graduates to be equipped with the necessary theory and practical aspect of the related industry in order to have a better chance in the job market. It is also due to the debt upon graduation which awaits most of the graduates from the education loan taken (Jones, 2010; Metcalf, 2005).

Motivation is also found to be statistically significant. As lecturer motivation will shape the way of how a class is being conducted and developing a good engagement with students, thus it theoretically explained the reasoning of the findings. A positive and motivated lecturer towards students contributed to an open learning environment in the class and strengthen the engagement between lecturer and students (Kunter et al., 2013). Therefore, a stress-free environment will exist. Thus, the students will feel belonged to the class and will perform better. Such environment reduces the barriers of obtaining feedback and communication between lecturer and students as the students feel connected with the lecturer and class overall. Thus, students will have a psychologically supported environment to communicate and ask for an opinion on the aspect of student life.

However, pedagogy found to be statistically not significant. Surprisingly, the result contradicted with a previous study (Douglas et al., 2006; Gruber et al., 2010; Kashif \& Ting, 2014; Muzenda, 2016; Santhi \& Ganesh, 2015). Pedagogy found to be statistically not significant due to the interactive learning taking place in the institution. As education is moving towards digitalization and a greater variety of learning platforms exist to support the knowledge delivery such as Google Classroom, Youtube and other platforms, this potentially explained the insignificance of the Pedagogy. Moreover, virtual class and long-distance learning trend nowadays also contributed to such findings. This is also supported by the shifting of the generation preferences and availability of existing alternatives. Compared to the previous days, the lecturer is the main source of information, thus the pedagogy knowledge is very important as the class was conducted mainly in classroom settings through traditional ways of the lecture. 


\section{Study Limitations}

This study focused on four aspects of lecturers' competencies while there are other variables that potentially affect the relationship. Moreover, the scope of service quality in higher institutions consisted of another aspect including facilities and brand reputation that can be another variable to be studied. Besides, different countries are having different education settings where these findings might not be applicable to these settings. The finding might not suit Malaysia's primary and secondary private and public schools as the setting and learning nature of these institutions are different. Other than that, the program fees studied are potentially affected by other variables such as the source of funding and might contribute towards different findings. Moreover, the study also has limited capabilities to reach respondents from each of the higher institutions that potentially give a different impact due to time constraints and budget limitations.

\section{Implications and Suggestions Theoretical}

The study confirmed the relationship between four lecturers' competencies variables in this digital era and provided the latest update based on current generation preferences and market. The study emphasized on the four variables of lecturers' competencies intensely as the main factor contributing to students' satisfaction in higher institution. Moreover, the program fees variable gave new insight in scholarly work of higher education quality since there are few studies conducted in order to examine the relationship of program fees toward student satisfaction as compared to other commercial transaction where it is proving to be significant. However, in the higher education industry, there is a very scarce amount of studies in order to confirm the relationship between the effects of price on service quality perception from the customer perspective. Thus, this study developed an overall model to define the relationship by considering all variables into one study framework.

\section{Practical}

As the study found a statistically significant relationship on three variables of lecturers' competencies, thus it is crucial for the institution and related bodies to focus on this aspect further. Knowledge, industrial experience and motivation aspect of lecturers are deemed necessary to be the main element to be considered by the related stakeholder when hiring a new lecturer. It should also be an element that has to be emphasized on lecturer training and career development by the institution. It is very crucial to supplement lecturers with enough support in order to ensure that they remained highly motivated. Professional placement in the related industry can be implemented purposely to update the lecturer with current practice in the industry besides building a good network with industry. Thus, the institution will remain relevant with the latest changes and demand in the related industry through the aligning of the program structure in order to supply the industry with a relevant and skilled workforce.

\section{Future Research Direction}

A same framework of the study can be implemented in a different country with a different setting such as first and third world countries in order to see how the economic condition of a different country affect student perception toward lecturers' competencies and will program fees affects the relationship. Different demographic setting in a different country 
potentially has a different effect on the relationship on the model. Besides, as there is plenty of private primary and secondary schools existing now, the study also can be conducted on this group of population. In addition, different variables of lecturers' competencies and other mediating variables can be included in order to see a wider perspective of the study. As the demand changes and customer preferences keep changing, thus any related variables can be tested to see and prove the relationship. Other than that, extend analysis on the source of fund obtains by a student also can be studied to see how the variables potentially affect the program fees towards the model.

\section{Conclusion}

To conclude, out of four variables tested on lecturers' competencies aspect, only three of the variables found to be statistically significant which are knowledge, industrial experience and motivation. While pedagogy is not significant statistically. Meanwhile, a multi-group analysis of private institution solely found that only industrial experience and motivation are statistically significant compared to the public institution where knowledge found to be an important factor in the study. Moreover, the path analysis between lecturers' competencies and programme fees indicated none of the variables were statistically significant when even multi-group analysis of private and public institutions was conducted. However, there is a statistically significant relationship between programme fees and students' satisfaction. The results contradicted with the finding on the commercial transaction in the consumer product industry. Thus, the programme fees do not affect student perception and satisfaction toward the lecturers' competencies, but it does affect student satisfaction directly. Therefore, there is no significant relationship of programme fees as a mediator between lecturers' competencies and students' satisfaction.

The findings supported the importance of institutions in delivering excellent service quality to the students mainly on the aspect of the lecture itself in order to maintain the institution sustainability. With such a positive and excellent service, the student will be satisfied and will lead to a positive word of mouth and become free marketing agents for the institution. Students also have the potential to repeat purchases or further their studies at the same institution. Thus, a good brand reputation of the institution can be developed.

\section{Acknowledgement}

This research was supported by the students of eight institutions listed. We are grateful to our colleagues and friends who provided the expertise that momentously assisted the research, even though they may have not reached a decision with all of the interpretations provided in this paper. We are also massively thankful for their comments on earlier versions of this paper, even though any faults are our own and should not tarnish the reputations of these respected professionals. 


\section{Corresponding Author}

\section{Muhammad Safuan Abdul Latip}

Tunku Abdul Rahman University College, Perak Campus

Malaysia

Email: safuan@tarc.edu.my

\section{References}

Annamdevula, S., \& Bellamkonda, R. S. (2016). The effects of service quality on student loyalty: the mediating role of student satisfaction. Journal of Modelling in Management, 11(2), 446-462. https://doi.org/10.1108/JM2-04-2014-0031

Arambewela, R., \& Hall, J. (2009). An empirical model of international student satisfaction. Asia Pacific Journal of Marketing and Logistics, 21(4), 555-569. https://doi.org/10.1108/13555850910997599

Ary, D., Razavieh, A., \& Jacobs, L. C. (1996). Introduction to research in education. Fort Worth, Texas: Harcourt Brace College Publication.

Awang, M. G. (2014). Pedagogy for lecturers. Pahang, Malaysia: Universiti Malaysia Pahang.

Awang, Z., Hui, L. S., \& Zainudin, N. F. S. (2018). Pendekatan Mudah SEM Structural Equation Modelling. Selanhor: MPWS Rich Resources Sdn. Bhd.

Azman, N., Idris, M. F. M., \& Siang, H. Y. (2014). Dialog meja bulat naib canselor memacu universiti di Malaysia ke arah kecemerlangan. Terengganu, Malaysia: Universiti Malaysia Terengganu.

Benjamin, S. J., Marathamuthu, M. S., Muthaiyah, S., \& Raman, M. (2011). Affordability of private tertiary education: A Malaysian study. International Journal of Social Economics, 38(4), 382-406 https://doi.org/10.1108/03068291111112068

Briggs, A. R., Coleman, M., \& Morrison, M. (2012). Research methods in educational leadership and management. London, United Kingdom: SAGE Publications.

Byrne, B. M. (1998). Structural equation modeling with LISREL, PRELIS, and SIMPLIS : basic concepts, applications, and programming. Multivariate Applications Book Series.

Carter, S., \& Yeo, A. C. M. (2016). Students-as-customers' satisfaction, predictive retention with marketing implications: The case of Malaysian higher education business students. International Journal of Educational Management. https://doi.org/10.1108/IJEM-092014-0129

Deaconu, A., Osoian, C., Zaharie, M., \& Achim, S. A. (2014). Competencies in higher education system: An empirical analysis of employers' perceptions. Amfiteatru Economic, 16(37), 857-873.

Douglas, J., Douglas, A., \& Barnes, B. (2006). Measuring student satisfaction at a UK university. Quality Assurance in Education, 14(3), 251-267.

https://doi.org/10.1108/09684880610678568

Dwenger, N., Storck, J., \& Wrohlich, K. (2012). Do tuition fees affect the mobility of university applicants? Evidence from a natural experiment. Economics of Education Review, 31(1), 155-167.

https://doi.org/10.1016/j.econedurev.2011.10.004

Gruber, T., Fub, S., Voss, R., \& Gläser-Zikuda, M. (2010). Examining student satisfaction with higher education services. International Journal of Public Sector Management, 23(2), 105-123. https://doi.org/10.1108/09513551011022474 
Hanapi, Z., \& Nordin, M. S. (2014). Unemployment among Malaysia Graduates: Graduates'Attributes, Lecturers' Competency and Quality of Education. Procedia-Social and Behavioral Sciences, 112. https://doi.org/10.1016/j.sbspro.2014.01.1269

Hassan, S. A., \& Ghazali, R. (2012). Quick tips fast track conducting quantitative research. Bangi, Selangor: Quty Researcher.

Hayes, A. F. (2013). Introduction to Mediation, Moderation and Conditional Process Analysis. In Journal of Chemical Information and Modeling. https://doi.org/10.1017/CBO9781107415324.004

Hooper, D., Coughlan, J., \& Mullen, M. R. (2008). Structural equation modelling: Guidelines for determining model fit. Electronic Journal of Business Research Methods, 6(1), 53-60.

Jones, G. (2010). Managing student expectations the impact of top-up tuition fees. Perspectives: Policy and Practice in Higher Education, 14(2), 44-48. https://doi.org/10.1080/13603101003776135

Kashif, M., \& Ting, H. (2014). Service-orientation and teaching quality: business degree students' expectations of effective teaching. Asian Education and Development Studies, 3(2), 163-180. https://doi.org/10.1108/AEDS-06-2013-0038

Khoo, S., Ha, H., \& McGregor, S. L. T. (2017). Service quality and student/customer satisfaction in the private tertiary education sector in Singapore. International Journal of Educational Management, 31(4), 430-444.

https://doi.org/10.1108/IJEM-09-2015-0121

Kunter, M., Klusmann, U., Baumert, J., Richter, D., Voss, T., \& Hachfeld, A. (2013). Professional competence of teachers: Effects on instructional quality and student development. Journal of Educational Psychology, 105(3), 805-820. https://doi.org/10.1037/a0032583

Letcher, D. W., \& Neves, J. S. (2010). Determinants of undergraduate business student satisfaction. Research in Higher Education Journal Determinants, 6(1), 1-26.

Metcalf, H. (2005). Paying for university: The impact of increasing costs on student employment, debt and satisfaction. National Institute Economic Review, 191(1), 106117. https://doi.org/10.1177/0027950105052662

Moreno-Murcia, J. A., Silveira Torregrosa, Y., \& Belando Pedreño, N. (2015). Questionnaire evaluating teaching competencies in the university environment. Evaluation of teaching competencies in the university. Journal of New Approaches in Educational Research. https://doi.org/10.7821/naer.2015.1.106

Munnukka, J. (2008). Customers' purchase intentions as a reflection of price perception. Journal of Product and Brand Management, 17(3), 188-196. https://doi.org/10.1108/10610420810875106

Muzenda, A. (2016). Lecturer's Competences and Students' Academic Performance. International Journal of Humanities and Social Sciences Invention, 380(21), 1839-1847. https://doi.org/10.1016/j.physleta.2016.03.037

Phan, A. C., Abdallah, A. B., \& Matsui, Y. (2011). Quality management practices and competitive performance: Empirical evidence from Japanese manufacturing companies. International Journal of Production Economics.

https://doi.org/10.1016/j.ijpe.2011.01.024

Potgieter, I. L., \& Coetzee, M. (2010). Management competencies in higher education: Perceived job importance in relation to level of training required. SA Journal of Human Resource Management, 8(1), 1-10. 
https://doi.org/10.4102/sajhrm.v8i1.306

Prasetio, A. P., Azis, E., Fadhilah, D. D., \& Fauziah, A. F. (2017). Lecturers' Professional Competency and Students' Academic Performance in Indonesia Higher Education. International Journal of Human Resource Studies, 7(1), 86-93. https://doi.org/10.5296/ijhrs.v7i1.10902

Santhi, R., \& Ganesh, R. (2015). Addressing service quality to increase students satisfaction and retention in Malaysian private Higher Education Institutions. American Journal of Economics, 5(2), 243-250.

https://doi.org/10.5923/c.economics.201501.31

Sekaran, U., \& Bougie, R. (2016). Research methods for business : a skill-building approach 7th edition. In John Wiley \& Sons Ltd. United Kingdom.

Seng, E. L. K. (2013). A qualitative study of factors contributing to international students' satisfaction of institutional quality. Asian Social Science, 9(13), 126-131. https://doi.org/10.5539/ass.v9n13p126

Tham, S. Y. (2013). Internationalizing Higher Education in Malaysia: Government Policies and University's Response. Journal of Studies in International Education, 17(5), 648-662. https://doi.org/10.1177/1028315313476954

Tuan, N. M. (2012). Effects of service quality and price fairness on student satisfaction. International Journal of Business and Social Science.

Voss, R., \& Gruber, T. (2006). The desired teaching qualities of lecturers in higher education: A means end analysis. Quality Assurance in Education, 14(3), 217-242. https://doi.org/10.1108/09684880610678540

Watjatrakul, B. (2014). Factors affecting students' intentions to study at universities adopting the "student-as-customer" concept. International Journal of Educational Management. https://doi.org/10.1108/IJEM-09-2013-0135

Wong, J., Tong, C., \& Wong, A. (2014). The Mediating Effects of School Reputation and School Image on the Relationship between Quality of Teaching Staff and Student Satisfaction in Higher Education in Hong Kong. British Journal of Education, Society \& Behavioural Science, 4(11), 1552-1582.

https://doi.org/10.9734/bjesbs/2014/11312 